\title{
KONTRADIKSI DUA SUMBER HUKUM UTAMA DIALEKTIKA HADITS AHAD DAN QIYAS
}

\author{
Muhammad Silahuddin $\bowtie$ \\ Sekolah Tinggi Ilmu Fikih (STIF) Syeikh Nawawi Tanara Serang Banten - Indonesia
}

\begin{abstract}
Abstrak
Artikel ini menunjukkan bahwa meskipun Sunnah/Hadits dan qiyas telah disepakati oleh empat madzhab (al-a'immat al-arba'ah) sebagai sumber hukum Islam (mashâdir alAhkam), selain Al-Qur'an dan ijmâ', namun terjadi penyimpangan antara mereka dan pengikutnya jika terjadi pertentangan (ta'ârudh) antara hadits al-âhâd dengan qiyâs, dalam hal ini digunakan sebagai dalil untuk menegakkan syariat/Hukum Islam. Mayoritas ulama sepakat untuk mengutamakan hadits al-âhâd daripada qiyâs sebagai dalil yang sah, syaratnya ketat, yaitu hadits al-âhâd harus shahih. Ditambahkan oleh Hanafiyah, hadits al-âhâd tidak terkait dengan hal-hal yang tidak dapat dihindari ('umûm al-balwâ), dan tidak berbeda dengan praktik perawi, serta tidak bertentangan dengan al-Qur'an dan/atau hadt mutâwatir. Ditambahkan oleh Imam Malik dan ulama Malikiyah, hadits al-âhâd tidak bertentangan dengan 'Amal Ahl al-Madînah, karena sifat kekuatan hukumnya sebagai kekuatan hukum hadts mutâwatir. Namun dalam konteks tertentu, Imam Malik menempatkan hadits al-âhâd daripada qiyâs dalam 4 (empat) masalah, yaitu hadits tentang: sesuatu/anjing menjilati bejana yang terkena, jual beli sistem musharrâh, jual beli sistem 'Arâyah, dan tentang al-qur'an. Demikian pula imam Malik menempatkan qiyas dari hadits al-âhâd dalam hal makan dan minum pada saat puasa karena lupa, adalah batal hukumnya, sehingga wajib dipenuhi (qadhâ'). Sedangkan pendapat para imam Hanafi yang mempelopori dan Syafii malah mendasarkan pada hadits al-âhâd yang diriwayatkan oleh Abu Hurairah, bahwa puasa itu tidak batal, sehingga harus diteruskan (ditingkatkan), dan tidak wajib dipenuhi (qadhâ').
\end{abstract}

Kata Kunci: hadits al-âhâd, qiyas, ta'arudh, istinbâth, al-madzâhib al-arba'ah 


\begin{abstract}
This article shows that even though the Sunnah/Hadîts and qiyâs has been agreed by four priests schools (al-a'immat al-arba'ah) as a source of Islamic law (mashâdir al-Ahkam), in addition to the Qur'an and ijmấ, but occurs deviation between them and their followers in the event of a contradiction (ta'ârudh) between hadits al-âhâd with qiyâs, in the case used as the arguments to establish Shari'ah/Islamic Law. The majority of scholars, agreed to prioritize hadits al-âhâd than qiyâs as legal proof, the condition strict, ie that hadits al-âhâd to be authentic. Added by Hanafiyah, hadits al-âhâd is not associated with things that can not be avoided ('umûm albalwâ), and not unlike the practice of narrators, and not in conflict with the Qur'an and/or hadîts mutâwatir. Added by Imam Malik and scholars Malikiyah, the hadits al-âhâd does not contradict with 'Amal Ahl al-Madînah, because of the nature of its legal force as the force of law hadîts mutâwatir. However, in certain contexts, Imam Malik put hadits al-âhâd than qiyâs in 4 (four) problems, namely the hadîts about: something/dog licking the affected vessel, musharrâh system purchase, sale and purchase of the system of 'Arâyah, and about qur'ah. Similarly, imam Malik put qiyâs than hadits al-âhâd in matters of eating and drinking at the time of fasting due to forget, is a legal void, making it obligatory to be fullfilment (qadhâ'). While the opinion of the Hanafi imams who pioneered and Syafii instead basing on hadits al-âhâd narrated by Abu Hurayrah, that the fast is not invalidated, so it should be forwarded (enhanced), and not obligatory to be fullfilment (qadhâ').
\end{abstract}

Keywords: hadits al-âhâd, qiyâs, ta'arudh, istinbâth, al-madzâhib al-arba'ah.

Copyright (c) 2021 Muhammad Silahuddin.

$\triangle$ Corresponding author : Muhammad Silahuddin

Email Address : muh.silahuddin@gmail.com

\title{
PENDAHULUAN
}

Islam, sebagaimana agama samawi lainnya, mempunyai landasan tuntunan (rule) yang bersumber ilahi, berupa wahyu yang ditransfer kepada seorang utusan yang terpilih, yaitu Nabi Muhammad Saw. Wahyu-wahyu tersebut telah dikodifikasikan (altadwin) menjadi sebuah kitab suci al-Qur'an. ${ }^{1}$ Sebagai landasan tuntunan utama alQur'an bersifat global (mujmal), yaitu prinsip-prinsip utama suatu tuntunan. Tuntunan tentang teologi (al-tauhid), tuntunan terkait ibadah (al-'ubudiyah) meliputi shalat, puasa, zakat, dan haji, tuntunan terkait dengan bagaimana berinteraksi dengan lainnya (al$m u^{\prime}$ amalah) misalnya interkasi dengan lingkungan sosial, pernikahan, bisnis, tuntunan terkait dengan hukum pidana maupun perdata, juga sejarah-serajah masa lalu yang memuat 'ibrah-'ibrah yang juga memuat nilai-nilai yang bisa menjadi tuntunan bagi manusia. ${ }^{2}$

${ }^{1} \mathrm{Hal}$ itu sebagaimana yang dijelaskan dalam beberapa ayat al-Qur'an, misalnya dalam surat al-Baqarah (2): 99, 105 dan 174, surat al-Maidah (5): 48, surat al-An'am (6): dan 155, surat al-Anfal (8): 42, surat Yusuf (12): 2, surat al-Ra'd (13): 37, surat Ibrahim (14): 1, dan surat al-Nahl (16): 64 .

${ }^{2}$ Ayat-ayat yang berisi tuntunan tentang shalat misalnya dalam surat al-Baqarah (2): 43, tuntunan terkait puasa misalnya dalam surat al-Baqarah (2): 183-185, tuntungan terkait dengan zakat misalnya dalam surat al-Baqarah (2): 110, tuntunan terkait dengan haji misalnya dalam surat al-Baqarah (2): 196-203. Ayat-ayat yang menjelaskan tuntunan tentang kehidupan sosial misalnya dalam surat al-Baqarah (2): 224 atau surat al- Hujarat (49): 13, tentang pernikahan misalnya pada surat al-Nisa (4): 1, tentang bisnis misalnya pada surat al-Nisa (4): 29. Tentang hukum pembunuh misalnya pada surat al-Baqarah (2): 85, surat al-Nisa (4): 92, surat al-Maidah (5): 52. Tentang hukum relasi suami-istri misalnya dalam surat al-Nisa (4): 34, atau tentang waris dalam surat al-Nisa (4): 11-12. 
Hanya saja, tuntunan-tunan al-Qur'an yang komprehensif tersebut bersifat global (mujmal), sehingga dibutuhkan penguraian (al-mubayyin) yang berfungsi menafsirkan pesan-pesan ayat al-Qur'an. ${ }^{3}$ Misalnya tuntunan al-Qur'an tentang shalat sebagaimana terdapat dalam surat al-Baqarah ayat 43. Dalam ayat tersebut Allah Swt tidak memberi penjelasan secara rinci terkait shalat. Akhirnya Nabi Saw sebagai utusanNya menjelaskan hal-hal yang terkait dengan ibadah shalat, tentang waktu-waktu shalat sebagaimana hadits Nabi Saw yang diriwayatkan oleh imam Muslim melalui sanad Ibn Umar r.a, atau hadits yang diriwayatkan oleh imam Bukhari dan imam Muslim melalui sanad Abu Hurairah r.a. ${ }^{4}$ Juga hal-hal lain terkait shalat, misalnya syarat shalat dan rukunnya dengan cara praktek langsung.

Penjelasan Nabi Saw atas ayat-ayat al-Qur'an baik melalui ucapan (al-qaul), tindakan (al-af'âl) maupun ketetapan (al-taqrîr) tentulah mempunyai peran dan fungsi yang sangat penting sekali. Oleh karena itu, para ulama memposisikan hadits pada tempat yang utama setelah al-Qur'an. Dalam melakukan istinbâth al-hukm (penggalian hukum) para ahli hukum Islam baik fuqaha (ahli fiqh) atau ushuliyun (ahli ushul fiqh) memposisikan hadits sebagai sumber hukum (mashdar al-hukm) utama setelah alQur'an.

Sumber hukum Islam bisa dikelompokkan menjadi dua kelompok besar. Pertama, sumber hukum yang disepakati oleh para ulama (al-muttafaq), di mana para ulama mazhab sepakat mengakui dan menjadikannya sebagai sumber hukum, meliputi al-Qur'an, hadits, ijma', dan Qiyas. ${ }^{5}$ Kedua, sumber-sumber hukum yang tidak disepakati (al-mukhtalaf), yaitu sumber-sumber yang masih debatable di kalangan para ulama mazhab, sebagian ulama menggunakannya sebagai sumber hukum dan sebagian ulama yang lain tidak menggunakannya sebagai sumber hukum. Sumber-sumber hukum dalam kategori ini meliputi: qaul shahabiy, istihsân, istishlâh atau mashâlih mursalah, 'urf, syarâ'i' sâbiqah, dan istishhab. ${ }^{6}$

Hadits Nabi Saw sebagai sumber hukum utama setelah al-Qur'an yang disepakai oleh para ulama, utamanya para ulama ahli hadits, mempunyai banyak kategori dengan sudut pandang yang bermacam. Diantara kategori tersebut adalah kategori bisa diterima atau tidaknya sebuah hadits, adakalanya berupa hadits shahih, hadits hasan dan hadits dla'if. ${ }^{7}$ Untuk dua macam hadits pertama para ulama sepakat bisa digunakan sebagai sumber hukum. Dan untuk macam hadits ketiga para ulama sepakat tidak bisa digunakan sebagai sumber hukum.

Kategori hadits lainnya adalah dari sudut transmisi penyampaian hadits (sanad). Dengan kategori ada tiga macam hadits, yaitu hadits mutawatir, hadits masyhur dan hlm. 91-91.

${ }^{3}$ Muhammad ibn Idrîs al-Syâfi'î̀, al-Risâlah (Mesir: Musthafâ al-Bayânî al-Halabî, 1938),

${ }^{4}$ Lihat Ibn Hajar al-'Asqalânî, Bulûgh al-Marâm min Adillat al-Ahkâm (Jakarta: Dâr alKutub al-Islâmiyyah, 2002), hlm. 3-5-36

${ }^{5}$ Lih. 'Abd al-Wahhâb Khallâf, 'Ilm Ushûl al-Fiqh (Kuwait: Dâr al-Qalam, 1972), Cet. ke10, hlm. 21.

${ }^{6}$ Penjelasan singkat tentang penerapan metodologi penggalian hukum (istinbâth al-hukm) dalam setiap mazhab sebagaimana berikut. Metodologi yang digunakan oleh Mazhab Hanafi adalah: al-Qur'an dan hadis, fatwa-fatwa para sahabat, qiyâs dan istihsân, serta 'urf. Metodologi yang digunakan oleh Mazhab Maliki meliputi: al-Qur'an dan hadits, ijmâ' Ahl al-Madînah, qiyâs, qawl al-shahabî, al-mashâlih al-mursalah, 'âdah, sadd al-dzarâi', istishhâb dan istihsân. Metodologi yang digunakan oleh mazhab Syafii antara lain: al-Qur'an dan hadits, ijma', qawl sebagian sahabat dan qiyâs. Adapun metodologi yang digunakan oleh Mazhab Hanbali adalah: al-Qur'an dan hadits, ijma', fatwa sahabat, istishhâb, al-mashâlih al-mursalah dan sadd al-dzarî'ah. Untuk lebih lengkapnya bisa dilihat dalam karya-karya Khallâf, 'Ilm Ushûl al-Fiqh, Muhammad Abû Zahrah, Ushûl al-Figh, dan Wahbah al-Zuhailî, Ushûl al-Figh al-Islâmî.

${ }^{7}$ Lihat. Muhammad ‘Ujâj al-Khatîb, Ushûl al-Hadîts : 'Ulûmuhu wa Musthâlahuhu (Beirut : Dar al-Fikr, 1989), hlm. 304 
hadits ahad. Para ulama sepakat dua macam hatis pertama bisa digunakan sebagai sumber hukum. Sedangkam hadits ahad para ulama perbedaan pendapat, ada yang berpandangan bisa dijadikan sebagai sumber hukum, dan ada yang berpandangan sebaliknya.

Dalam tulisan ini, penulis akan mengurai lebih panjang keabsahan hadits ahad sebagai sumber hukum Islam. Utamanya dealiktika kekuatan hadits ahad sebagai sumber hukum ketika terjadi kontradiksi ( $\left(a^{\prime} a r u d l\right)$ dengan qiyas yang status keduanya sama-sama disepakati oleh para ulama (muttafaq) sebagai sumber hukum. Dengan dealiktika ini akan diketahui sumber hukum mana diantara keduanya yang banyak diakui oleh para ulama sebagai sumber hukum yang rajih (patut).

Apalagi untuk menjawab kebutuhan hukum yang selalu muncul dan berkembang, akan selalu dibutuhkan kajian dan pencermatan terhadap sumber-sumber hukum, utamanya hadits Nabi Saw, sebagai sumber hukum yang utama setelah alQur'an. Mengingat sumber utama hukum Islam yaitu al-Qur'an dan hadits tidak akan bertambah maka mengurai al-Qur'an melalui tafsir-tafsir ayatnya dan mencermati substansi hadits melalui syarah dan penjelasanya untuk memberi solusi hukum atas masalah-masalah kekinian yang selalu muncul merupakan suatu keniscayaan. ${ }^{8}$ Tentu akan selalu dibutuhkan usaha-usaha kreasi hukum melalui nalar dalam ijtihad dengan berdasar validitas sumber hukum sehingga bisa memenuhi tuntutan hukum yang sesuai ruang (al-makân) dan waktu (al-zamân).

\section{METODOLOGI}

Tulisan ini menggunakan metode deskriptif analisis di dukung oleh data yang di peroleh melalui library research atau penelitian keperpustakaan. Library research atau penelitian keperpustakaan ini, penulis melakukan dengan mempelajari, menelaah dan mengkaji buku-buku, al-Qur'an dan Hadits, dan lain sebagainya yang erat kaitannya dengan masalah yang di bahas. Penelitian ini menggunakan pendekatan filosofis, yaitu berusaha memecahkan masalah dengan usaha pemikiran mendalam dan sistematis. Terkait dengan penilitian ini penulis berusaha meneliti dengan mengikuti cara dan alur pikiran dari empat madzhab (al-a'immat al-arba'ah) sebagai sumber hukum Islam (mashâdir al-Ahkam), selain Al-Qur'an dan ijmâ' serta tokoh yang di teliti hingga diperoleh dasar pemikiran..

\section{HASIL DAN PEMBAHASAN}

\section{Memahami Hadits Ahad Dan Qiyas}

A. Hadits dan kekuatan hukumnya

Ada beberapa kata yang sinonim (muradif) dengan kata "hadits" yaitu "sunnah" dan "khabar". ${ }^{9}$ Para ahli hadits (al-muhadditsun), ahli ushul fiqh (al-ushuliyun) dan ahli fiqh (al-fuqaha) ketika mendefinisikan hadits hampir tidak ada perbedaan, yaitu setiap ucapan (al-qaul), tindakan (al-fi'l), ketetapan (al-taqrîr) Nabi Muhammad Saw. ${ }^{10}$ Hanya

${ }^{8}$ Lihat Ibn Rusyd, Bidâyat al-Mujtahid wa-Nihâyat al-Muqtashid (Beirut: Dâr al-Fikr, 2005), hlm. $1 / 5$.

${ }^{9}$ Lihat Muhammad 'Ajâj al-Khathib, Ushûl al-Hadîts: 'Ulûmuhu wa-Musthalâhuh (Beirut: Dâr al-Fikr, 1989), hlm. 27. Di samping itu ada istilah lain yang serupa, yaitu hadits Qudsi, hadist yang langsung disandarkan nabi Muhammad Saw kepada Allah Swt. jumlah hadist qudsi sebagaimana yang dikompilasikan oleh Ibnu Hajar al-Haitamî dalam Syarh al-Arba'în alNawawiyyah mencapi lebih dari seratus hadist, sedangkan menurut al-Munâwî dalam al-Ittihâfât al-Saniyyah bi-al-Ahâdits al-Qudsiyyah mencapi 272. Lihat al-Khathib, Ushûl al-Hadîts, hlm. 29.

${ }_{10}$ Definisi ini sebagaimana yang terdapat dalam banyak kitab ushul fikh. Misalnya dalam Al-Ghazâlî, al-Mustashfâ (Beirut: Dâr al-Kutub al-'Ilmiyyah, 1996), hlm. 105, Jalâl al-Dîn al-Mahallî, Syarh Jam’ al-Jawâmi' (Libanon: Dâr al-Fikr al-'Arabî, 1995), Juz II, hlm. 95, 
saja sebagian ulama ushul fiqh menambahkan definisi, yaitu "yang bisa menjadi dasar hukum".11 Berdasarkan definisi tersebut, tampak perbedaan terminologi antara kelompok ahli hadits dan ahli ushul figh; terminologi para ahli hadits lebih luas karena mencakup semua yang berasal dari Nabi Saw, sedangkan terminologi para ahli ushul fiqh lebih terfokus pada hadits-hadits yang hanya bisa dipakai sebagai landasan hukum (mashdar al-hukm). Kalau dibaca dari sisi disiplin keilmuan, pembatasan definisi yang diberikan oleh para ahli ushul fiqh di sini bisa diterima, karena setiap disiplin keilmuan akan condong mendefinisikan sesuatu sesuai dengan disiplin keilmuan dan sudut pandang masing-masing.

Ditinjau dari sudut transmisinya hadits (sanad) menurut mayoritas ulama, selain ulama Hanafiyah, hadits dikategorikan 2 macam, sebagaimana telah disebutkan sebelumnya, yaitu hadits mutawatir dan hadits ahad.12 Sedangkan menurut ulama Hanafiyah ada 3 (tiga) kategori, selain dua kategori sebelumnya sebagaimana kategori yang disepakati oleh mayoritas ulama, ada satu kategori lagi, yaitu hadits masyhur. ${ }^{13}$

Kekuatan hukum hadits mutawatir adalah qath'iy al-tsubût, sebagaimana kekuatan hukum al-Qur'an, ${ }^{14}$ karena transmisinya sampai kepada para sahabat adalah secara tawâtur (beruntun) sehingga kebenarannya (al-'ilm) ayat-ayat al-Qur'an ataupun hadits-hadits Nabi Saw sangat bisa diyakini dan tidak terbantahkan (dharûrî). Kekuatan ayat-ayat al-Quran ataupun hadis mutawatir, ditinjau dari sudut penunjukannya (dilâlah) terhadap hukum, ada yang berkekuatan hukum zhannî, yang masih butuh pengkajian lebih lanjut (nazharî) untuk membuktikan kebenaran dan mendapatkan keyakinannya. ${ }^{15}$ Sedangkan hadits masyhur, yakni hadits yang tidak mencapai kategori hadits mutawatir, ${ }^{16}$ kekuatan hukumnya qath'iy al-wurûd, hanya sampai pada sahabat, tetapi tidak sampai qat'iy al-tsubut, sehingga kekuatan hukumnya hanya sebatas sebagai penopang (al-thuma'nînah) atas hadits yang lain, masih dibutuhkan kajian lanjutan untuk memperkuat hukumnya karena mendekati zhann.

Macam dan ragam hadits diatas serta kekuatan posisinya sebagai sumber hukumnya mempunyai konsekuensi hukum. Konsekuensi hukum orang yang mengingkari hadits mutawatir adalah dikategorikan sebagai orang kafir. Sedangkan orang yang mengingkari keberadaan hadits kategori masyhur konsekuensi hukumnya tidak sampai mengakibatkan dirinya dianggap fasiq. ${ }^{17}$

Hadits ahad merupakan hadits yang secara sanad tidak mencapai kategori hadits masyhur, apalagi hadits mutawatir. ${ }^{18}$ Mayoritas ulama (ulama Hanafiyah, Syafi'iyah, Malikiyah) berpendapat bahwa hadits ahad hanya berkekuatan hukum zhann saja. ${ }^{19}$ Hanya saja, mereka berbeda pendapat tentang kekuatan hadits ahad sebagai sumber hukum. Pertama, kelompok yang berpandangan, bahwa mengamalkan hadits ahad

Muhammad ibn 'Alî al-Syaukânî, Irsyâd al-Fuhûl ilâ Tahqîq 'Ilm al-Ushûl (Makkah: Muassasat alKutub al-Tsaqafiyyah, 1993), hlm. 67.

11Lihat al-Khathib, Ushûl al-Hadîts, hlm. 19.

12 Al-Ghazali, Al-Mustashfâ, , Juz I, hlm. 93, dan al-Syaukânî, Irsyâd al-Fuhûl, Juz II, hlm.

186.

${ }^{13}$ Lihat kitab-kitab al-Talwîh 'alâ al-Taudhîh, Juz II, hlm. 2, al-Taqrîr wa a--Tahbîr, Juz II, hlm. 235, Mir'at al-Ushûl, Juz II, hlm. 200.

${ }^{14}$ Apalagi dalam surat al-Najm ayat 3-4 disebutkan bahwa apa yang disampaikan oleh Nabi Saw adalah wahyu. Saif al-Dîn ibn Abî 'Alî al-Âmidî, al-Ihkâm fi Ushûl al-Ahkâm (Beirut: Dâr al-Fikr, 1996), Juz I, hlm. 151, Abu al-Barakat Abdullah al-Nasafî, Kasyf al-Arâr (Beirut: Dâr alKutub al-'Ilmiyyah, t.t), Juz I, hln, 680..

15 Lihat Muhammad 'Ajâj al-Khathib (2), Ushûl al-Hadîts: 'Ulûmuhu wa-Musthalâhuh (Damaskus: Dâr al-Fikr, 1971), hlm. 301-302.

16al-Khathib (2), Ushîl al-Hadîts, hlm. 302.

${ }^{17}$ Al-Zuhailî, Ushûl al-Figh al-Islâmî, hlm. 453 dan 454.

${ }^{18}$ Lihat al-Khathib (2), Ushîl al-Hadîts, hlm. 302.

19 Lihat al-Ghazâlî, al-Mustashfâ, Juz I, hlm, 93-99. 
secara syara' adalah wajib. Kelompok ini melandaskan pada konsensus para sahabat; tidak sedikit di antara para sahabat yang menggunakan hadits ahad sebagai landasan hukum secara tawâtur. Di antaranya, Abu Bakar r.a yang menggunakan hadits ahad yang sanadnya berasal dari al-Mughirah bin Syu'bah r.a tentang bagian waris 1/6 (seperenam) bagi nenek perempuan (jaddah). ${ }^{20}$ Juga ketika para sahabat sepakat menggunakan hadits ahad yang berasal dari 'Aisyah r.a tentang wajibnya mandi ketika melakukan senggama (iltiqấ al-khitanain). ${ }^{21}$ Juga hadits ahad tentang tidak batalnya puasa seseorang ketika mencium istrinya, sebagaimana yang berasal dari Ummi Salamah r.a. ${ }^{22}$

Kedua, kelompok yang berpendapat bahwa menggunakan hadits ahad secara syara' dan logika adalah wajib. Pandangan ini dipegangi oleh imam Ahmad, al-Qaffal al-Syasyî, Ibn Suraij dan Abû al-Husain al-Bashrî. ${ }^{23}$ Arugumen yang digunakan oleh kelompok ini sama dengan argumen yang digunakan kelompok pertama, hanya saja kelompok ini menambahkan argumen bahwa secara nalar ('aqli) hadits ahad yang diriwayatkan oleh perawi yang adil tentu patut diterima. Bahkan, ketika Nabi S.a.w. masih hidup, setiap muncul suatu permasalahan maka direspon langsung oleh beliau sebagai sebuah solusi, yang di antara responnya kemungkinan berupa hadits yang masuk ke dalam kategori hadits ahad. ${ }^{24}$

Hadits ahad pada dasarnya tidak sedikit jumlahnya, dan tidak sedikit pula yang digunakan sebagai landasan hukum oleh para sahabat. Misalnya hadits tentang kepemimpinan pasca wafatnya Nabi Saw. Para sahabat menggunakan hadits sebagaimana yang diriwayatkan oleh imam Muslim dengan sanad yang berasal dari Abu Bakar r.a., yang terkenal sebagai hadîts al-Tsaqîfah. Hadits tersebut masuk dalam kategori hadits ahad 25

B. Qiyas dan Kekuatan Hukumnya

Qiyas atau analogical reasoning merupakan suatu metode istinbâth hukum yang menempati posisi keempat, dari sumber-sumber hukum yang disepakati oleh para ulama. Apabila dicermati, maka tidak sedikit produk hukum Islam, fiqh, yang dihasilkan melalui istinbâth dengan menggunkan pendekatan qiyâs, terlebih lagi pasca mandegnya wahyu, baik dalam bentuk ayat-ayat al-Qur'an, hadits qudsi maupun hadits Nabi Saw. Para ulama menilai bahwa semua produk hukum fiqh yang dihasilkan oleh metode qiyâs ini benar-benar valid dan memiliki kekuatan hukum yang dapat dipertanggung-jawabkan secara rasional.

Secara etimologis (lughawî), qiyâs adalah memperkirakan sesuatu, atau membandingkan 2 (dua) hal untuk diketahui kesamaan di antara keduanya, ${ }^{26}$ baik yang kasat (hissî) atau yang intuitif (ma'nawî). Secara terminologis (ishthilahî) para ahli ushul fiqh telah banyak memberikan definisi tentang qiyâs, di antaranya definisi yang banyak dikemukakan yaitu, menyamakan hukum sesuatu yang tidak ada nash-nya terhadap hukum sesuatu yang sudah ada nashnya, dikarenakan ada kesamaan dalam causa

${ }^{20}$ Lihat hadits sebagaimana yang diriwayatkan Malik dalam kitâb al-Farâ'idh, bâb mirâts al-jaddah, 2/513, Abû Dâwud, kitâb al-farâ'idh, bâb fi al-jaddah, nomor 2894, al-Tirmidzî, kitâb alFarâ'idh, bab fi mirâts al-jaddah, no. 2101, Ibn Mâjah, kitâb al-farâ'idh, bâb mirâts al-jaddah, no. 2724.

21Sebagaimana yang diriwayatkan oleh Ahmad, 6/239.

22Sebagaimana yang diriwayatkan Malik, dalam kitab al-shiyâm, bab mâ jấa fî al-rukhshah fì al-qubûlah lî al-shâ'im, Juz I, hlm. 291-292

${ }^{23}$ Al-Mu'tamad, 2/106, nihayah al-Suwal, 2/321, al-Bahr al-Muhith, 6/131

24 Muntaha al-Wushul, 76, Syarh Mukhtashar Ibn al-Hajib, 2/61, al-Mustashfa, 1/147,

Ushul al-Fiqh karya Abu al-Nur, 3/139

25 Lihat. Jami' al-Ushul. 4/437, Majma' al-Zawaid, 5/192.

26 Al-Âmidî, al-Ihkâm, Juz III, hlm. 1, Muslim al-Tsubut. 2/195, Syarh al-Isnawy. 3/1, alSyaukânî, Irsyâd al-Fuhûl, hlm. 173. 
hukumnya (al-'illah).27 Dalam definisi ini secara implisit ditekankan bahwa aktifitas qiyâs adalah membuka dan memperlihatkan suatu hukum (al-kasyf wa al-izhhâr), bukan menetapkan dan memunculkan suatu hukum (al-itsbât wa al-insyấ). Dalam hal ini, suatu hukum sudah ada dan telah menetap pada sesuatu yang menjadi sandaran qiyâs (almaqîs 'alaih). Proses istinbâth hukum melalui qiyâs itu sendiri hanya munculkan hukum untuk sesuatu yang di-qiyaskan (al-maqîs), yaitu cabang, karena adanya kesamaan 'ilat (causa) hukum.

Secara metodologi dan operasional, qiyâs merupakan upaya menghubungkan satu peristiwa dengan peristiwa lain yang memiliki justifikasi hukum dengan melihat adanya persamaan kausa hukum ('illat). Dengan adanya persamaan kausa inilah, maka kasus yang pertama itu ditetapkan dan diberikan ketentuan hukumnya. Imam Syafi'i sebagai perintis metode qiyâs dalam fiqh telah membuat kualifikasi yang ketat terhadap unsur-unsur yang ada pada qiyâs. Menurutnya qiyâs dapat berlaku dan memiliki kekuatan hukum yang valid jika keempat syaratnya terpenuhi, yaitu ashl (pokok), hukm al-ashl (hukum yang ada pada pokok), furû' (cabang), dan 'illat (alasan/sebab hukum).

Sungguhpun qiyâs termasuk sumber hukum yang disepakati oleh para ulama, akan tetapi tingkat penerimaannya sebagai sumber hukum bervarisi, sebagai berikut:28

1. Kelompok mayoritas (jumhûr) berpendapat bahwa menggunakan qiyâs dalam masalah ibadah, secara akal boleh (jấiz) dan secara syara' wajib menjalankannya. Al-Qaffâl dan Abû al-Husain al-Bashrî al-Mu'tazilî mengatakan bahwa secara nalar dan dalil naqli qiyâs wajib dilakukan. ${ }^{29}$

2. Kelompok al-Qâsânî, al-Nahrawânî, dan al-Ashfihânî: qiyâs hanya bisa dilakukan apabila illat hukum ashl (asal) ada nash-nya, baik secara jelas (sharîh) maupun secara isyarat ( $\left.\hat{\imath} m \hat{a}^{\prime}\right)$, serta apabila hukumnya fara' lebih utama dari $a s h l .{ }^{30}$

3. Kelompok Zhâhiriyah dan al-Syaukanî: qiyâs secara akal boleh (jấiz), tetapi hal itu secara syara' tidak diwajibkan.

4. Kelompok Syî́ah Imâmiyah dan al-Nazhzhâm dari aliran Mu'tazilah: qiyâs dalam hal ibadah adalah tidak mungkin (mustahîl), karena dalam qiyâs akan muncul 2 (dua) hal yang kontradiktif (al-tanaqudl). Dalam hal ini, tampak jelas bahwa pandangan al-Nazhzhâm tidak berbeda dengan pandangan al-Qâsâniy.

Sebagai ringkasan, dari pendapat-pendapat di atas dapat dikelompokkan ke dalam 2 (dua) bagian, yaitu kelompok mayoritas yang berpendapat bahwa qiyâs bisa menjadi hujjah secara mutlak, dan kelompok lain yang berpendapat bahwa qiyâs tidak bisa menjadi hujjah. Sungguhpun demikian, kelompok kedua ini ada yang berpandangan bahwa qiyâs tidak bisa menjadi hujjah karena secara nalar ('aql) tidak bisa

27al-Syairâzî, al-Lumâ', hlm. 51, Mir'at al-Ushûl, Juz II, hlm. 275, Raudlhat al-Nadhir, Juz II, hlm. 227, Miftât al-Wushûl ilâ Binâ' al-Furû' 'alâ al-Ushûl, hlm. 91, Ushûl al-Fiqh karya Zakî al-Dîn Sya'bân, hlm. 59 .

28al-Mahallî, Jam' al-Jawâmi', Juz II, hlm 177, Mukhtashar Ibn Hâjib ma'a Syarh al-'Adhad, Juz II, hlm. 248 dan 251, al-Ghazâlî, al-Mustashfâ, Juz II, hlm. 56, 69, dan 70, al-Âmidî, al-Ihkâm , Juz III, hlm. 64, Ushûl al-Syâsî, hlm. 91, Ibn 'Arabî, Risalât fi Ushûl al-Thâhiriyyah, hlm. 20, Ibn Faurak, Risâlat fi Ushûl al-Fiqh, hlm. 12, al-Taudhîh, Juz II, hlm. 53, Kasyf al-Asrâr, Juz II, hlm. 990, al-Taqrîr wa-al-Tahbîr, Juz III, hlm. 242, al-Ibhâm, Juz III, hlm. 5, Syarh al-Isnawî, Juz III, hlm. 11, Raudhat al-Nadhîr, Juz II, hlm. 224, al-Syaukânî, Irsyâd al-Fuhûl, hlm. 174, 178, 228, dan Fawâtih alRahamût, Juz II, hlm. 211.

${ }^{29}$ Menurut Ibn al-Subkî, qiyâs merupakan bagian dari agama, dengan berlandaskan pada surat al-Hasyr ayat 2

${ }^{30}$ Contohnya adalah, peng-qiyasan haramnya memukul kedua orang tua kepada mengatakan "uff" (memarahi) dengan illat karena sama-sama menyebabkan sakit. Hal itu sebagaimana nash al-Qur'an surat al-Isra' [17] ayat 23 : Di mana, hukum haramnya memukul kedua orang tua adalah lebih utama daripada haramnya berkata "uff" karena menimbulkan sakit. 
diterima; dan ada yang berpandangan bahwa qiyâs tidak bisa menjadi hujjah karena secara syara' tidak bisa diterima.

\section{Kontradiksi Hadits Ahad Dan Qiyas}

Sebagaimana telah dikemukakan di atas, bahwa hadits Nabi Saw dan qiyas merupakan sumber hukum yang disepakati penggunaannya oleh para ulama mazhab, yakni ditempatkan sebagai sumber hukum kedua setelah al-Qur'an dan qiyas sebagai sumber hukum keempat setelah ijma'. Di antara sumber hukum, tidak bisa dihindarkan apabila di antara sumber hukum, baik yang disepakati maupun yang tidak, kadangkala terjadi $t a^{\prime}$ ârudh (kontradiksi). Di antara penyebabnya adalah perbedaan cara pandang dan metode berfikir para ulama mazhab dalam penggalian hukum. Juga adanya perbedaan konteks zaman dan waktu yang melingkupi ulama dalam menggali hukum, sehingga tidak heran ketika dalam suatu masalah terdapat ikhtilaf hukum di antara para ulama.

Tidak jarang terjadi $t a^{\prime} a ̂ r u d h$ antar sumber hukum, misalnya ketika hadits ahad ta'ârudh dengan qiyas. Atau antar sumber hukum lain, qaul shahabî, mashlahah mursalah, sadd al-dzarâ'i' atau 'urf. Ta'ârudh juga terjadi antar kaidah-kaidah fiqh, atau kaidahkaidah ushuliya. Untuk mendapatkan kajian yang mendalam, penulis hanya mengfokuskan pada pandangan para ulama terhadap posisi hadits ahad ta'ârudl dengan qiyâs sebagai sebuah dialektika dalam penetapan hukum Islam. Keadaan ini tentu berbeda dengan kedudukan hadits mutawatir, karena tidak mungkin ta'ârudh dengan qiyâs.

Menurut mayoritas ulama, ketika terjadi ta'ârudh antara hadits ahad dan qiyâs maka hadis ahad harus lebih diutamakan dibandingkan qiyâs. Yang tergolong dalam kelompok pendapat masyoritas ini adalah imam Abu Hanifah dan ulama-ulama Hanafiyah, seperti Ibn al-Hammam, Ibnu Amir al-Haj, Amir Badisyah dan al-Baharî, Imam Malik dan ulama-ulama Malikiyah, seperti al-Sam'anî, Abû al-'Abbas alQurthûbî, al-Muthi'î, al-Syanqithî, dan al-'Ilwanî, Imam Syafi'i dan ulama-ulama Syafiiyah, seperti al-Bashrî, al-Sam'aniy, al-Bazdawî, al-Ghazalî, al-Razî, al-Zanjanî, alBukharî, al-Isnawî dan al-Zarkasyî. Begitu pula imam Ahmad bin Hambal dan ulamaulama Hanabilah, seperti Abu Ya'lâ, al-Kalwadzanî, Ibnu 'Aqil dan Badran. ${ }^{31}$

Akan tetapi dalam suatu riwayat, imam Malik dan ulama Malikiyah dalam beberapa hal lebih mendahulukan qiyâs daripada hadits ahad sebagai sumber hukum secara mutlak tanpa syarat apapun (sebagaimana contoh yang akan dikemukakan di bawah ini). Akan tetapi menurut sebagian ulama, pendapat ini dianggap tidak kuat dan tidak bisa dipertanggungjawabkan.32 Untuk mengamalkan hadits ahad, ulama Malikiyah mensyaratkan bahwa hadits ahad tidak bertentangan dengan apa yang diamalkan oleh masyarakat Madinah ('amal ahl al-Madînah), karena sifat kekuatan hukum dalam 'amal ahl al-Madinah adalah sebagaimana kekuatan hukum hadits mutawatir. ${ }^{33}$ Menurut Ibn Amir al-Haj dan Amir Badasyah, ada 4 (empat) hadits ahad yang didahulukan oleh imam Malik daripada qiyâs, ${ }^{34}$ yaitu hadits tentang

${ }^{31}$ Al-Qarâfî, Syarh Tanqîh al-Fushûl fî Ikhtishâr al-Mahshûl fi al-Ushûl, hlm. 279, al-Âmidî, al-Ihkâm, Juz II, hlm. 345, ibn al-Hâjib, al-Mukhtashar, Juz II, hlm. 73, al-Bukhârî, Kasyf al-Asrâr, Juz II, hlm. 378, Ibn al-Subkî, al-Ibhâj, Juz V, hlm. 1863, al-Zarkâsyî, al-Bahr al-Muhîth, Juz IV, hlm. 343, Ibn al-Hammâm, al-Tahrî̀, hlm. 352, Ibn Amir al-Hâjj, al-Taqrîr wa-al-Tahbîr, Juz II, hlm. 298, Amîr Bâdâsyah, Taysîr al-Tahrîr, Juz III, hlm. 116, dan al-Syâfi'î, al-Risâlah, hlm. 599.

${ }^{32}$ Lih. Mukhtashar Ibn 'Abd al-Hakam, 4/371.

${ }^{33}$ Ihkâm al-Fushûl, hlm. 413-414, Ibn Rusyd, al-Muqaddimat fi al-Figh, Juz IV, hlm. 481, alMuqaddimah fì al-Ushûl, hlm. 77.

${ }^{34}$ Al-Taqrir wa al-Tahbir, 2/298, Taysir al-Tahirir, 3/116. 
sesuatu/bejana yang terkena jilatan anjing,, 35 hadits tentang jual beli sistem musharrâh, ${ }^{36}$ hadits tentang jual beli dengan sistem 'arâyâ, ${ }^{37}$ dan hadits tentang qur' $a h .{ }^{38}$

Para ulama yang lebih mendahulukan hadits ahad dibandingkan qiyâs dalam menetapkan hukum syara' berargumen dengan hadits yang diriwayatkan oleh Abu Dawud dan Ibnu Majah, yaitu hadis tentang Nabi S.a.w. mengutus Mu'adz bin Jabal r.a. ke Yaman. ${ }^{39}$ Secara implisit redaksi hadits tersebut menunjukkan bahwa menggunakan hadits sebagai sumber hukum itu lebih didahulukan daripada qiyâs dengan tanpa membedakan antara hadits yang mutawatir dengan yang ahad ataupun dengan yang masyhur. Mereka juga berargumen bahwa Abu Bakar r.a pernah menggagalkan keputusan yang sudah pernah dibuatnya karena mendengar sebuah hadits yang berasal dari Bilal bin Rabah r.a.

Meskipun demikian, mendahulukan hadits ahad daripada qiyâs dalam istinbâth hukum, para ulama sepakat membuat syarat khusus, yaitu hadits ahad tersebut harus diriwayatkan oleh seorang rawi yang muslim, ${ }^{40}$ sudah mukallaf, ${ }^{41}$ adil, kuat ingatannya (dlâbith), dan tidak melakukan pembohongan redaksi hadits (tadlîs), ${ }^{42}$ dan sanadnya muttashil, tidak berbeda dengan hadits yang diriwaytkan oleh rawi lain yang lebih bisa dipercaya (syadz), serta tidak ada cacat pada sanad ataupun matan-nya. ${ }^{43}$ Di samping itu, ulama Hanafiyah menambahkan syarat secara khusus, yaitu hadits ahad tersebut tidak terkait dengan hal-hal yang tidak bisa dihindari ('umûm al-balwâ), ${ }^{44}$ hadits yang diriwayatkan tidak berbeda dengan apa yang diamalkan oleh rawi-nya, ${ }^{45}$ dan tidak bertentangan dengan al-Qur'an atau hadits yang mutawatir. ${ }^{46}$ Begitupula ulama Syafi'iyah dan Hanabilah juga menambahkan syarat khusus, yaitu sanad hadits ahad tersebut harus sahih dan muttashil. ${ }^{47}$

35 Al-Bukhari, 172, Muslim, 89-93, 279-280

36 Al-Bukhariy, 2148, 2151, Muslim, 23-28, 1524

37 Al-Bukhariy, 2173, Muslim 59-66, 1539

${ }^{38}$ Al-Muwattha', hlm. 1459-1460, al-Mudawwanah, Juz IV, hlm. 322, Shahîh al-Muslim, Kitab 56, hlm. 1668, Sunan Abu Dawud, hlm. 3958, Sunan Ibn Majah, hlm. 2345.

${ }^{39}$ Lih. Musnad Ahmad, Juz V, hlm. 230, 236, 242, Sunan al-Dârimî, 168, Sunan Abu Dawud, 3592, 3593, Sunan al-Tirmidziy, 1327, 1328, al-Thabraniy fi al-Kabir, 20/170, dan Sunan al-Baihaqiy, $10 / 114$

40 Para ulama berbeda pendapat, ketika seorang rawi ketiak menerima hadits masih dalam keadaan muslim lalu ia menjadi kafir. Ada yang berpendapat riwayatnya tetap tidak bisa diterima sebagaimana dalam al-Mustashfa, Syarh Mukhtasar Ibn al-Hajib juga Muntaha alWushul. Dan ada yang berpendapat bisa diterima asalkan ia diyakini tidak akan berbohong, sebagaimana dalam al-Mahshul juga al-Bahr al-Muhith. Lihat al-Ghazâlî, al-Mustashfâ, Juz I, hlm. 157, Ibn al-Hâjib, Syarh al-Mukhtasar, Juz II, hlm. 62, Muntahâ al-Wushul, hlm. 77, al-Mahshûl, Juz IV, hlm. 394, al-Bahr al-Muhîth, Juz VI, hlm. 14.3

41 Mayoritas ulama menambahkan, kalau seorang perawi ketika menerima sebuah hadits masih kecil (shabiy) lalu ia menyampaikan hadits tersebut setelah ia dewasa (baligh) maka hadits yang diriwayatkannya bisa diterima. Seperti hadits yang diriwayatkan oleh Ibn 'Abbas, Ibn al-Zubair, atau riwayatnya Mahmud bin al-Rabi'. Lihat Ihkâm al-Fushul, hlm. 290-291, alGhazâlî, al-Mustashfâ, Juz I, hlm. 156.

${ }^{42}$ Al-Syaukâî, Irsyâd al-Fukhûl, Juz I, hlm. 214, al-Bahr al-Muhîth, Juz VI, hlm. 140.

${ }^{43}$ Lihat Fath al-Mughîts, Juz I, hlm. 221-225, Syarh Nuhkbat al-Fikr, hlm. 251-252, Taujîh alNadhar ilâ Ushul al-Atsar, hlm. 69.

${ }^{44}$ Kasyf al-Asrâr 'an Ushûl al-Bazdawî̀, Juz III, hlm. 35, al-Taqrîr wa-al-Tahbîr li-Ibn Amîr alHajj, Juz II, hlm. 295-296.

${ }^{45}$ Syarh al-Taudlih li-Matn al-Tanqih fi Ushul al-Figh, Juz II, hlm. 13, al-Bardisî, Ushûl alFiqh, hlm. 203, al-Dârinî, Buhûts Muqarânah fi al-Fiqh al-Islâmî̀, hlm. 156.

${ }^{46}$ Muhammad Abû Zahrah, Ushûl al-Figh (Mesir: Dâr al-Fikr al-'Ârabî, t.t), hlm. 104-105, 'Alî Hasbullah, Ushûl al-Tasyrî' al-Islâmî̀, hlm. 65,

${ }^{47}$ al-Mahshûl, Juz IV, hlm. 454, Syarh Mukhtashar al-Raudlah, Juz II, hlm. 228, al-Tahanawî, Qawấ'id fi 'Ulûm al-Hadîths, hlm.138. 
Contoh dari dialektika antara hadis ahad dengan qiyâs tersebut di adalah masalah qadha puasa bagi orang yang makan atau minum pada siang hari ketika berpuasa karena lupa. ${ }^{48}$ Ulama Syafi'iyah dan Hanafiyah berpendapat bahwa barangsiapa makan atau senggama pada siang bulan Ramadhan sebab lupa, maka orang tersebut tidak wajib mengqadha puasanya, juga ia tidak wajib membayar kafarat. Ulama Syafi'iyah dan Hanafiyah berargumen dengan hadits yang diriwayatkan oleh Abu Hurairah: "Barang siapa sedang berpuasa, lalu ia makan atau minum karena lupa, maka dia tetap harus meneruskan puasanya sampai selesai". ${ }^{49}$

Penalaran hukum demikian berbeda dengan penalaran hukum ulama Malikiyah yang berpendapat bahwa orang tersebut tetap wajib mengqadha puasanya. Dalam hal ini ulama Malikiyah tidak menggunakan hadits ahad yang diriwayatkan dari Abu Hurairah r.a tersebut, karena bagi mereka hadits tersebut dipandang bertentangan dengan qiyas. Mereka meng-qiyaskan batalnya puasa dengan batalnya ibadah-ibadah yang lain, yaitu ketika di antara rukun-rukunnya tidak terpenuhi. Sedangkan tidak makan dan senggama pada siang hari merupakan salah satu rukun puasa, sehingga ketika orang yang berpuasa tersebut makan dan minum pada siang hari, meskipun karena lupa, maka dia berarti menghilangkan salah satu rukun puasa, sehingga secara otomatis puasanya menjadi batal. ${ }^{50}$

Dari contoh dialektika hadis ahad dan qiyâs dalam menetapkan hukum syara' di atas penulis memadang bahwa pendapat pertama (yang dipelopori oleh imam Hanafi dan imam Syafi'i) yang menggunakan dasar hukum hadits yang sanadnya berasal dari Abu Hurairrah r.a. adalah lebih kuat (râjih), dibanding dengan pendapat kedua (yang dipelopori imam Malik) yang menggunakan landasan hukum qiyâs. Hal ini karena pendapat pertama banyak didukung oleh dalil lain, seperti hadits yang diriwayatkan dari Abu Hurairah r.a.: "Barangsiapa yang lupa bahwa ia sedang berpuasa, kemudian ia makan dan minum, maka sempurnakanlah puasanya. Sesungguhnya Allah yang memberinya makan dan minum. ${ }^{51}$ Ditambah lagi ada hadits yang berasal dari Ibn Abbas: "Dimaafkan atas ummatku karena kekeliruan, lupa dan karena dipaksa."52 Berdasarkan hadits kedua di atas, secara eksplisit bisa dipahami bahwa lupa bisa menghilangkan beban perintah (taklîf).

\section{KESIMPULAN}

Berdasarkan analisis di atas diperoleh kesimpulan bahwa terdapat perbedaan pendapat diantara mazhab fiqh (al-madzhahib al-fiqhiyah) mengenai dialektika antara hadis ahad dengan qiyas sebagai sumber hukum. Mayoritas ulama, seperti imam Abu Hanifah dan ulama-ulama Hanafiyah (Ibn al-Hammâm, Ibn Amîr al-Hâjj, Amir Bâdâsyah atau al-Bahariy dll), Imam Malik dan ulama-ulama Malikiyah (al-Sam'anî, Abu al-Abbas al-Qurthûbî, al-Muthi'î, al-Syanqithî dan al-'Ilwanî), imam Syafi'i dan ulama-ulama Syafiiyah (seperti al-Bashriy, al-Sam'aniy, al-Bazdawiy, al-Ghazaliy, alRaziy, al-Zanjaniy, al-Bukharî, dan al-Isnawî al-Zarkasyiy), dan imam Ahmad bin Hambal dan ulama-ulama Hanabilah (seperti Abu Ya'lâ, al-Kalwadzanî, Ibn 'Aqil, dan Badran). Para ulama yang sepakat mendahulukan hadits ahad daripada qiyas.

${ }^{48}$ Lihat juga Mushthafâ Sa'id Khîn, Atsar al-Ikhtilâffi al-Qawấ'id al-Ushûliyyah fí Ikhtilâf alFuqahâ', Cet. ke-7 (Beirut: Muassasat al-Risâlah, 1998), hlm. 423.

${ }^{49}$ Muslim, Shahîh al-Muslim, hadis no. 1952, bab akl nasiy, Ahmad, hadis no. 9125 bab musnad Abu Hurairah.

${ }^{50}$ Lih. Taqiy al-Dîn Daqị̂ al-'Aid, Ihkam al-Ahkâm Syarh 'Umdat al-Ahkâm (Mesir: Maktabat al-Sunnah, 1994), hlm. 395-396.

51 Shahîh al-Bukhârî, Juz II, hlm, 682, hadis no. 1831, Shahîh al-Muslim, Juz VI, hlm. 2455 hadis no. 6292, Sunan al-Nasa'î, Juz II, hlm. 244, hadis no. 3275, Sunan Ibn Majah, Juz I, hlm. 535, hadis no. 1673, dll.

${ }^{52}$ Sunan al-Thabranî, Juz II, hlm. 97, hadis no. 1430. 
Mereka mensyaratkan hadits tersebut harus diriwayatkan oleh seorang rawi yang muslim, mukallaf, adil, kuat ingatannya (dlâbith), dan tidak melakukan pembohongan redaksi hadits (tadlîs), sanadnya muttashil, tidak berbeda dengan hadits yang diriwayatkan oleh rawi lain yang lebih bisa dipercaya (syadz), dan tidak ada halhal yang menjadikan sanad maupun matan-nya cacat. Di samping itu, ulama Hanafiyah menambahkan syarat secara khusus, hadits ahad tersebut tidak tekait dengan hal-hal yang tidak bisa dihindari ('umum al-balwa), hadits yang diriwayatkan tidak berbeda dengan apa yang diamalkan oleh rawi-nya, dan tidak bertentangan dengan al-Qur'an atau hadits yang mutawatir. Begitu pula ulama Syafi'iyah dan Hanabilah yang juga menambahkan syarat khusus, yaitu sanad hadits ahad tersebut harus shahih dan muttashil. Imam Malik dan ulama Malikiah mensyaratkan hadits ahad tersebut tidak bertentangan dengan apa yang dipraktekkan oleh masyarakat Madinah ('amal ahl alMadînah), karena sifat kekuatan hukum dalam 'amal ahl al-Madînah sebagaimana kekuatan hukumnya hadis mutawatir.

Akan tetapi, Imam Malik mendahulukan hadis ahad daripada qiyas dalam 4 (empat) masalah, yaitu hadits tentang sesuatu/bejana yang terkena jilatan anjing, hadits tentang jual beli sistem musharrâh, hadits tentang jual beli dengan sistem 'arâyâ, 53 dan hadits tentang qur'ah. Demikian pula, menurut imam Malik dalam masalah makan dan minum di waktu puasa karena lupa, hukumnya batal, sehingga wajib diqadha', didasarkan pada qiyas, bukan hadis ahad. Pendapat ini berbeda dengan pendapat (yang dipelopori oleh imam Hanafi dan Syafi'i) yang menyatakan puasanya tidak batal, sehingga harus diteruskan (disempurkan) dan tidak wajib di-qadha", didasarkan pada hadis ahad, yaitu riwayat Abu Hurairah. Pendapat yang terakhir ini penulis pandang lebih rajih karena lebih banyak didukung oleh hadis yang lain, yang menguatkan.

\section{DAFTAR PUSTAKA}

Abû Bakr ibn Ahmad ibn Qâdlî Syubhah. Thabaqât al-Syâfi'iyyah. Beirut: 'Alim al-Kutub, 1407.

Abû Dâwud, Sulaiman ibn al-Asy'ats, al-Sajistanî al-Azdî. Sunan Abî Dâwud,. Beirut: Dâr al-Fikr, t.t.

Abû Zahrah. Ushûl al-Fiqh. Kairo: Dâr al-Fikr al-'Arabî, t.t.

al-Âmidî, Saif al-Dîn 'Ali ibn Abî 'Alî. Al-Ihkâm fi Ushûl al-Ahkâm. Beirut: Dâr al-Fikr, 1996.

al-Ghazâlî. Al-Mustashfâ. Beirut: Dâr al-Kutub al-'Ilmiyyah, 1996.

al-Mahallî, Jalâl al-Dîn. Syarh Jam' al-Jawâmi'. Libanon: Dâr al-Fikr al-'Arabî, 1995.

al-Qazwinî, Muhammad ibn Yazîd Abî 'Abdillâh. Sunan Ibn Mâjah. Beirut: Dâr al-Fikr, t.t.

al-Nasafî, Abû al-Barakat 'Abdillâh. Kasyf al-Arâr. Beirut: Dâr al-Kutub al-'Ilmiyyah, t.t. al-Nasâ'î, Ahmad ibn Syu'aib Abû 'Abd al-Rahman. al-Mujtabâ min al-Suna. Editor 'Abd al-Fattâh Abû Ghadah. Cet. ke-2. Halb: Maktab al-Mathbû'at al-Islâmiyyah, 1406.

al-Sarakhsî, Muhammad ibn Ahmad. Al-Mabsûth. Beirut: Dâr al-Ma'rifah, 1406.

al-Syâfi'î, Muhammad ibn Idrîs, al-Umm. Cet. ke-2. Beirut: Dâr al-Ma'rifah, 1393.

al-Syâthibî, Ibrâhîm ibn Mûsâ. Al-Muwâfaqât fî Ushûl al-Syarî’ah. Beirut: Dâr al-Kutub al'Ilmiyyah, t.t.

al-Syaukanî, Muhammad ibn 'Alî. Nail al-Authâr min Ahâdits Sayyid al-Akhyâr Syarh Muntaqa al-Akhbâr. Beirut: Dâr al-Jail, 1973.

al-Syaukânî, Muhammad ibn 'Alî. Irsyâd al-Fuhûl ilâ Tahqî̀ 'Ilm al-Ushûl. Makkah: Muassasat al-Kutub al-Tsaqafiyyah, 1993.

${ }^{53}$ Menurut ulama Syafi'iyah, bai' 'araya adalah, menjual kurma basah yang ada di pohon dengan kurma kering yang ada di tangan, dengan takaran yang telah ditetapkan syariat. 
DOI: https://doi.org/10.55252/annawawi.v1i1.5

al-Syairâzî, Abû Ishâq Ibrâhîm ibn 'Alî ibn Yûsûf. Thabaqât al-Fuqahâ'. Beirut: Dar alQalam, $\mathrm{t}$.

al-Zuhailî, Wahbah. Ushûl al-Fiqh al-Islâmi. Beirut: Dâr al-Fikr, 1986.

Ibn Hajar al-'Asqalânî. Nukhbat al-Fikr fi Mushthalâh Ahl al-Atsar. Beirut: Dâr Ihyâ' alTurâts al-'Arabî, t.t.

Ibn al-Rusyd. Bidâyat al-Mujtahid fi Nihâyat al-Muqtashid. Semarang: Thoha Putra, t.t. Khallâf, 'Abd al-Wahhâb. 'Ilm Ushûl al-Figh. Cet. ke-10. Kuwait: Dâr al-Qalam, 1972. Mahfudh, Sahal. Al-Tsamrah al-Hâjiniyah. Kajen: Maktabah Muassasah Nurussalam, t.t. al-Khathib, Muhammad 'Ajâj. Ushûl al-Hadîts: 'Ulûmuhu wa-Musthalâhuh. Beirut: Dâr alFikr, 1989.

Sa'id, Mushthafâ Khin, Atsar al-Ikhtilâffi al-Qawấ'id al-Ushûliyah fi Ikhtilâf al-Fuqahâ. Cet. ke-3. Beirut: Muassasat al-Risâlah, 1998.

‘Umr Ridhâ Kahâlah. Mu'jam al-Mu'allifin. Beirut: Dâr Ihyâ' al-Turats al-'Arabî, t.t. 